\title{
Development of Moodle E-Learning Media in Industrial Revolution 4.0 Era
}

\author{
Nur Aulia Khairani \\ PostGraduate, Universitas Negeri Medan \\ Medan, Indonesia \\ e-mail: nurauliakhairani1406@gmail.com
}

\author{
Juniastel Rajagukguk \\ PostGraduate, Universitas Negeri Medan \\ Medan, Indonesia \\ e-mail:juniastel@unimed.ac.id
}

\author{
Derlina \\ PostGraduate, Universitas Negeri Medan \\ Medan,Indonesia \\ e-mail: derlina.nst@gmail.com
}

\begin{abstract}
This study aims to produce moodle e-learning media that is feasible to use as a medium for learning the physics of geometric optical matter. The main problem is in the current era of industrial revolution 4.0, teachers as the front guard in the world of education are able to improve competence in facing the era of industrial revolution 4.0. One of the demands is that the teacher must be able to develop learning media according to the industrial revolution 4.0 as developed in this research, namely moodlee-learning media. This type of research is Research and Development and the development model used is the model of the development of 4-D. The instruments used in this study include learning device instruments and data collection instruments. The results of the study are that it has moodle e-learning media that is suitable for use as a medium for learning the physics of geometric optical matter.
\end{abstract}

\section{Keywords-Development, Moodle, E-Learning Media}

\section{INTRODUCTION}

At present, the world is entering the era of the fourth industrial revolution known as the industrial revolution 4.0 where technology is the basis of the deep human life. Everything becomes limitless and unlimited the development of the internet and digital technology. Lee et al [1] explained that the industrial revolution 4.0 was characterized by an increase in digitalization of manufacturing driven by four factors: 1) increased data volume, computing power, and connectivity; 2) the emergence of analysis, capability and business intelligence; 3) the occurrence of new forms of interaction between humans and machines; and 4) improvement of digital transfer instructions to the physical world, such as robotics and 3D printing. Liffler \& Tschiesner [2] added, the basic principle of industry 4.0 is combining machines, workflows, and systems, by applying intelligent networks along the chain and the production process to control each other independently.

Students who live in the millennial era spend more free time reading news, chatting, stalking, Instagram, WhatsApp, Facebook, Twitter, and many more using smartphones. Contemporary era students are more interested in living in cyberspace than in the real world. This habit is also carried away in the teaching and learning process. Present-day learners like to be in control, do not want to be bound by an additional schedule, they do not really like sitting in the classroom to study, do not like one-way communication, do not like conventional reading such as books, and know more about technology than parents including teachers. Instead, they prefer to use technology to study anytime, day or night, and do telecommunications from anywhere.

The same thing is also true for researchers when making observations at the Taman siswaTapian Dolok Private High School. Based on the results of observations it is known that physics lessons are one of the lessons that students do not like so that students experience saturation by the way teachers deliver lessons. Most teachers use the same method to convey all subject matter, namely the lecture method. Teachers tend to use media that are less varied and innovative, which is only limited to blackboards and chalk. This situation is still far from the expectations of millennial era students who want to use information and communication technology in learning. Students want learning to be done anytime and anywhere without having to be limited by space and time. Learning can even be done through their hands by utilizing existing smartphones.

The impact of all this is that the learning outcomes of students are still far from the standard minimum completeness criteria that have been determined. The school has provided learning media by utilizing the development of information and communication technology such as the availability of infocus. The school also has computer laboratory facilities equipped with internet connection access. It's good when the school has facilitated the needs of the process of teaching and learning activities so that teachers can take advantage of existing facilities to prepare students to face the industrial revolution 4.0. Teachers must be able to make a new innovation in learning by developing learning media that is packaged in such a way that learning is more interesting, interactive and effective and efficient in its use.

One solution to the problem found at the Tapian DolokTaman siswa Private High School is to use the latest information and communication technology to improve the quality of education. Technology in the world of education is usually called e-learning. The benefit of using e-learning facilities is to facilitate the learning and learning process. Elearning can be an alternative solution and technology for use in learning methods that are in accordance with the demands of the current and future industrial revolution 4.0.

The process of organizing e-learning requires a system that is able to manage learning online, a system commonly used known as LMS (Learning Management System). E-learning 
developed with LMS must be dynamic and comprehensive by incorporating learning material and able to accommodate learning systems that regulate the role of teachers, the role of students, management of learning, utilization of learning resources, monitoring the development of learning and evaluation systems. One of the supporting software for the LMS model used is Moodle. Moodle (Modular Object Oriented Dynamics Learning Environment) is a software package that can be used freely designed to develop internet-based learning activities and websites. Some of the facilities provided by the moodle include: reading menus, chat menu assignment menus, forum menus, choice menus, quiz menus, and so on [3].

Moodle is an application program that can transform learning media into web forms. The benefits of using LMS using moodle online are very important, including in accordance with the needs of millennial era students who want an easy learning process to be accessed anytime and anywhere.

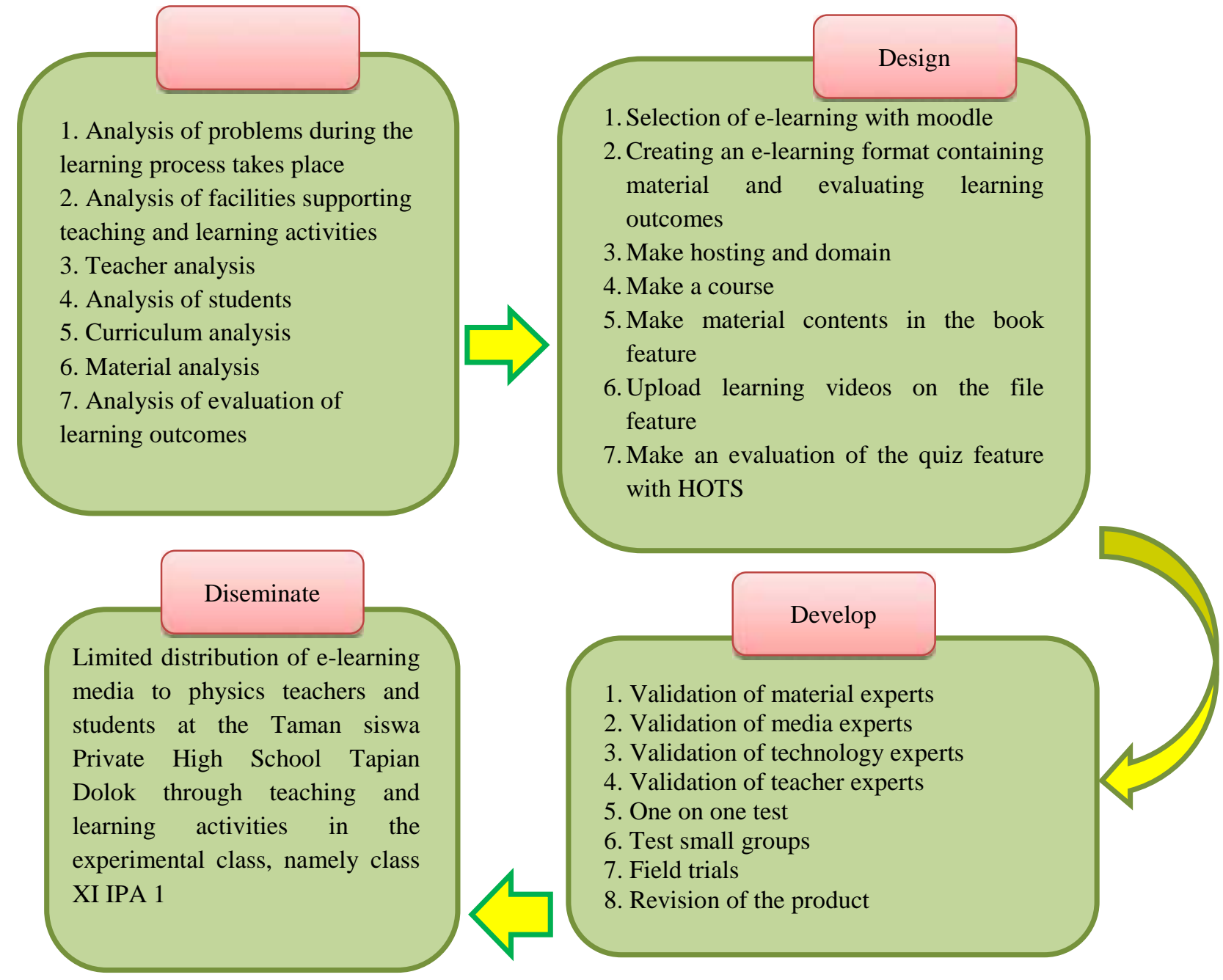

Fig 1. 4D Development Model

Hartanto \&Purbo [4] state that there are several reasons for using Moodle to improve teaching, namely: (1) being able to provide students with access to course materials in a controlled environment so that learning can take place anywhere; (2) monitor progress and keep students' learning records; (3) expanding the class by providing online discussions, evaluations, activities, and most importantly enabling collaboration and communication for learning; (4) utilizing attractive multimedia, interactive 3D media, and website-based content that enables students with different learning styles to access the curriculum; and (5) help science educators collaborate, share and store teaching resources.

\section{RESEARCH METHOD}

This research was conducted at Taman siwa Private High School Tapian Dolok, Tapian Dolok District, Simalungun District, North Sumatra. This type of research is Research and Development. This study uses a combination approach, namely an approach that combines quantitative and qualitative research methods. The development model used was a model for the development of S. Thiagarajan 4-D.The steps of research and development with the 4-D model are shown in the following figure. 


\section{RESULT}

\section{A. Design Stage}

After an analysis of several things in the previous stage, then the design phase (design) is carried out. At this stage, the researcher makes the design of the learning media product as a whole (storyboard), compiling the material, questions and answers, making the background, images, and logos that will be included in the application.

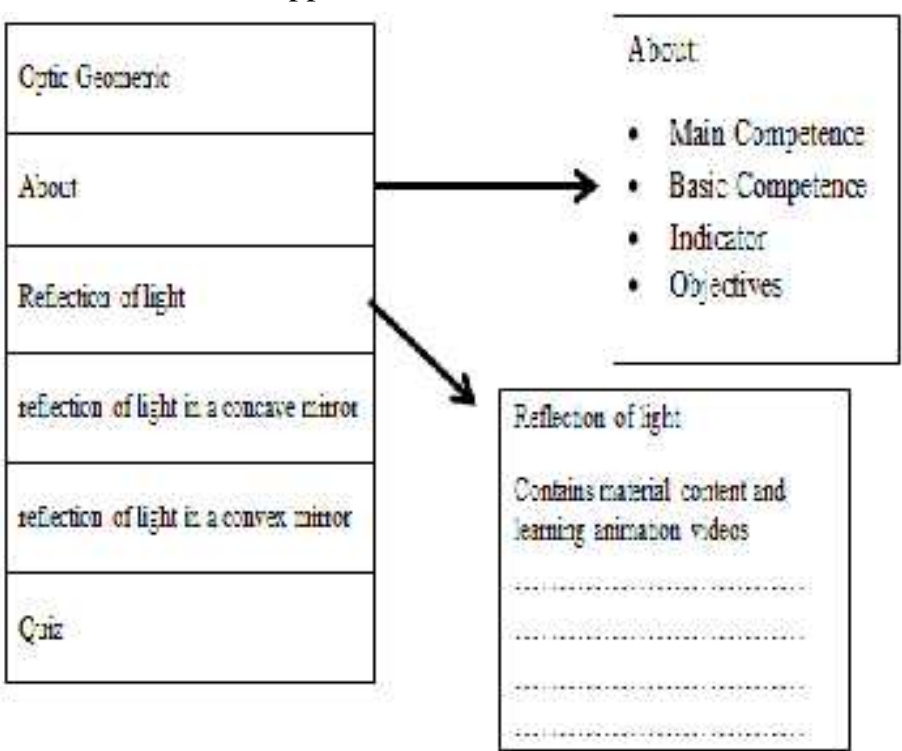

Fig. 2. Storyboard 1 Menu Display

The flowchart serves to help design the navigation structure from one view to the next so that it will clarify the design of making media. The following is a learning media flowchart.

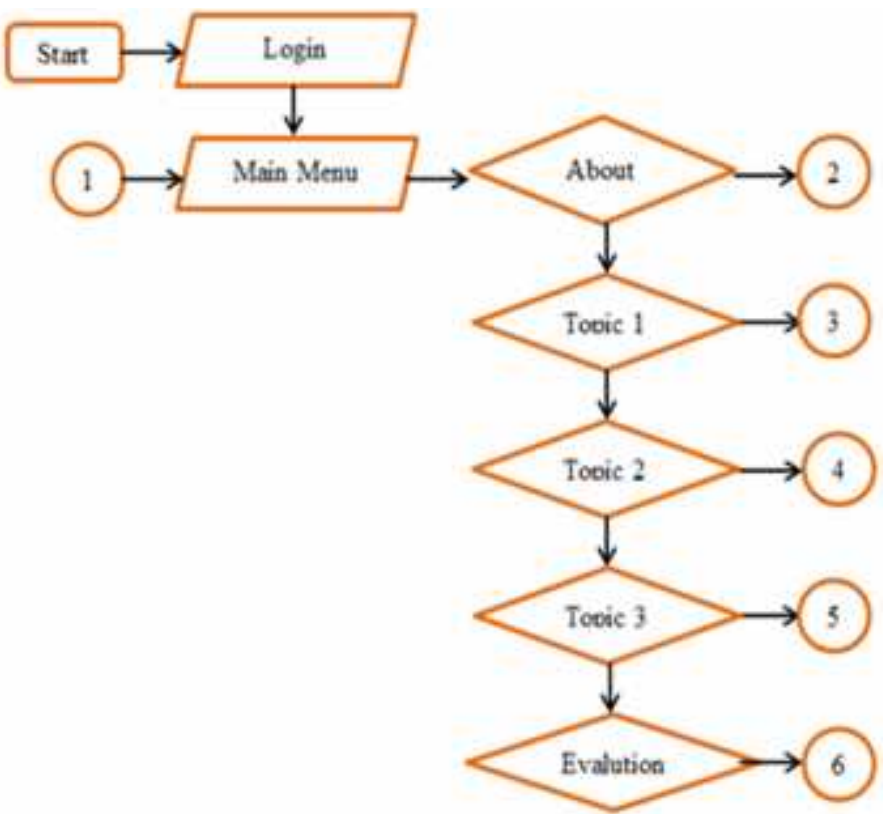

Fig. 3. Main Menu Flowchart

Figure 3 is a display of the main page of moodle-based elearning media. The main menu presented is a menu about, material 1 , material 2 , material 3 , and evaluation

\section{B. Develop Stage}

Based on observation result of student activity during The researcher developed the moodle e-learning media that had been made in the previous stage. At this stage the product is the result of development in the form of moodle e-learning media, expert assessment and product trial results.

The first step in this development is to create hosting by logging into c-Panel as shown in the image below.

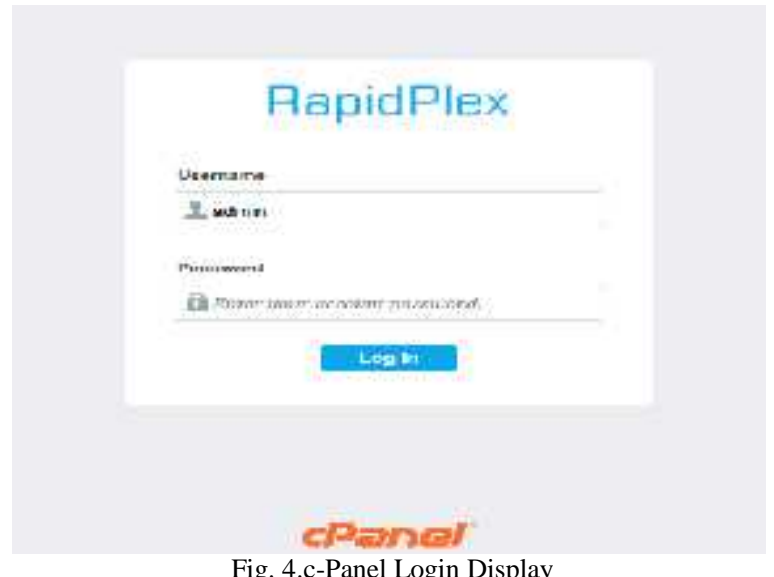

Write the admin in the username column and type the password in the password column. After entering c-Panel Hosting, search for moodle to be installed according to importance. The process of installing Moodle looks like the following picture.

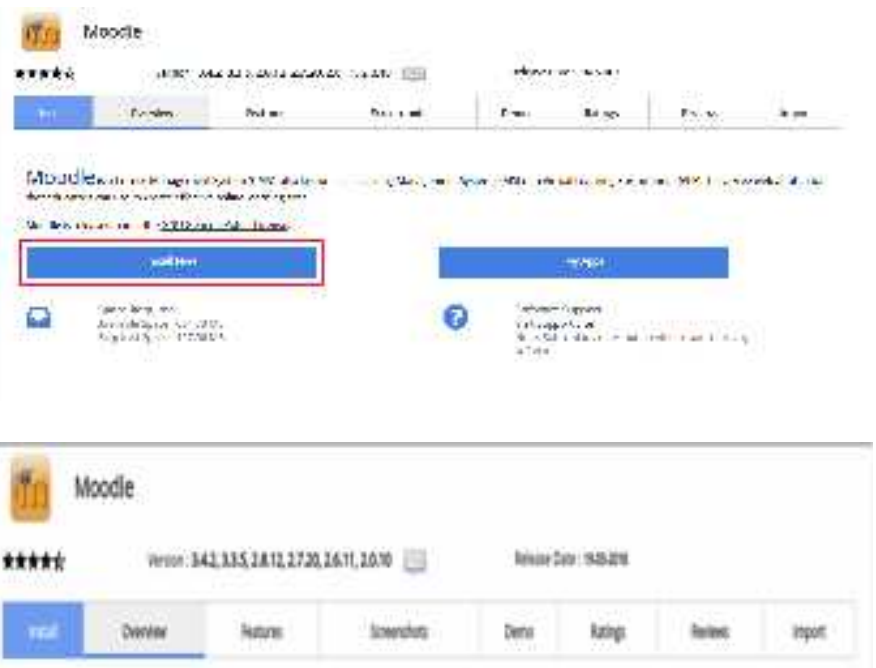

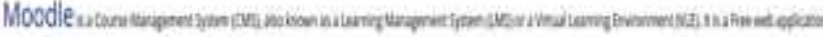

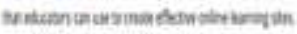

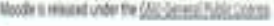

\section{val aw}

wisipant

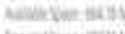

tementisy

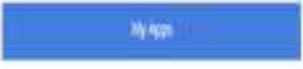

?

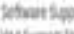

eshavily

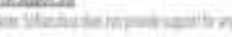

Fig. 5. Moodle Instalation 
The moodle installation process is complete then the elearning media start page is shown in the picture below.

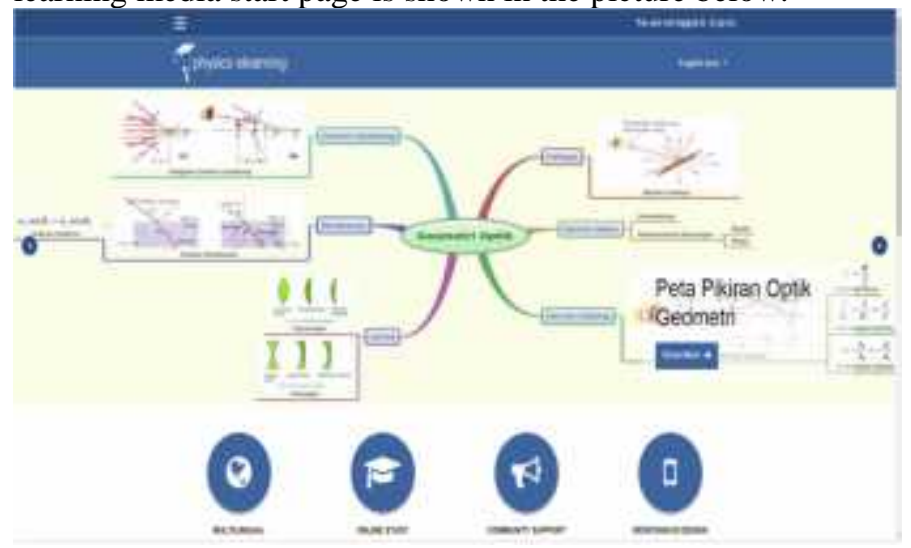

Fig. 6. E-Learning Media Start Page

Figure 6 shows the start page of the media that has been developed under the name identity e-learning physics. At the top right there is the text you are not logged in (Login) which means that each user must log in first before going to their respective portals. The display of the login page is shown in the image below.

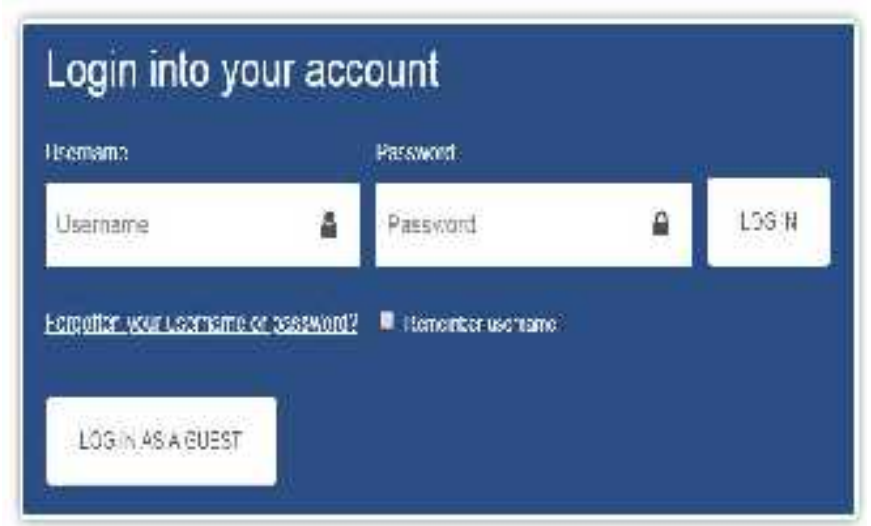

Fig. 7. Log-in Page

Figure 7 shows the display form of the e-learning media login page that has been developed. Each user must enter a username and password to be able to enter the e-learning media account. The username and password are obtained from the admin. Admin plays a very big role in regulating e-learning media. An admin is in charge of managing the site in general. An admin is tasked with managing e-learning media sites in general, for example managing the appearance of the site, creating courses, adding learning topics, adding users and much more. In this study researchers acted as admin. Admin's identity must be clearly visible so a profile photo must be installed. This will make it easier to be accessed by respondents.

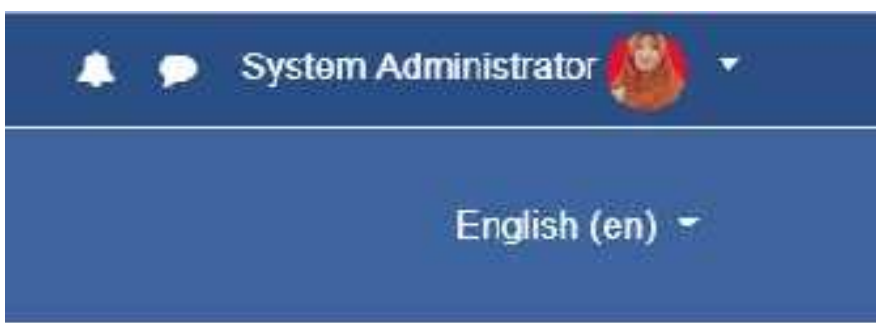

\section{CUSTOMISE THIS PAGE}

Fig. 8. Admin Identity

Making courses with the name "Optical Geometry" which consists of three topics. These topics include reflection of light, reflection of light in a concave mirror, and reflection of light on a convex mirror.

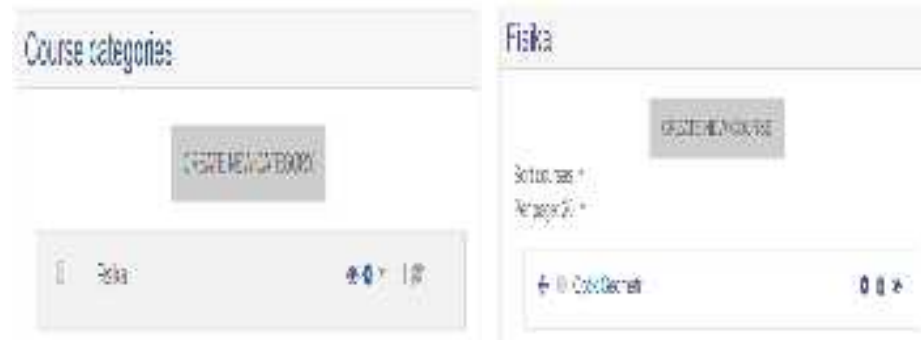

Fig. 9. Manufacture of course categories and new courses

The previous step is making the course with the name course namely Optical Geometry. Optical Course Geometry is filled with topics that contain any material contained in the chapter on Optical Geometry. These topics include reflection of light, reflection of light in a concave mirror, reflection of light on a convex mirror and daily replications. The following is a display of media topics developed:
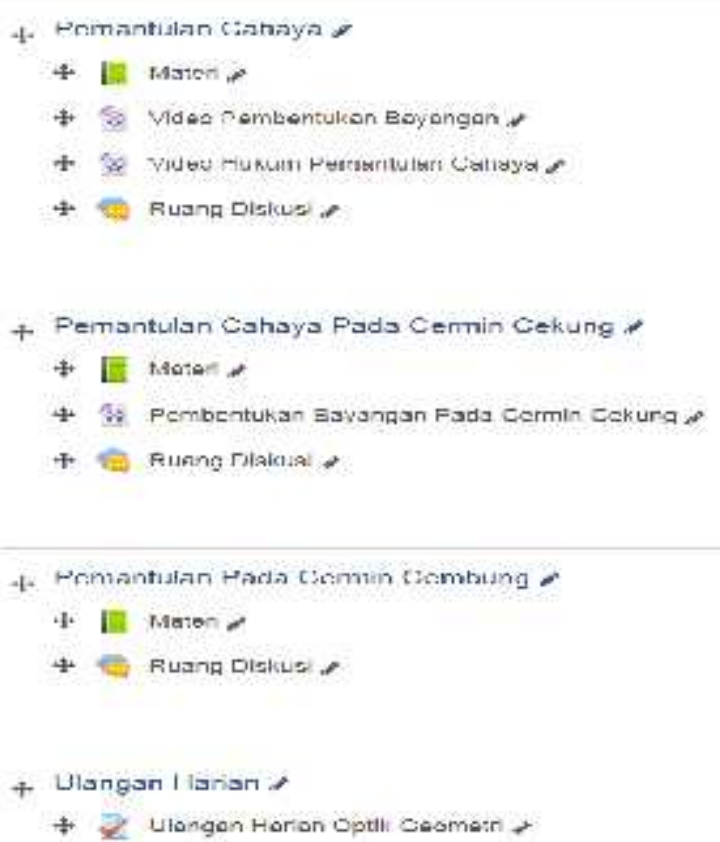

Fig. 10. Display of Media Topics

Making material content that will be uploaded to elearning using the book feature. The reason for choosing this feature is because the book feature is equipped with the font type and font size settings to be used, equation facilities for 
making formulas in physics material, picture facilities for inserting images that can clarify the material description, and video facilities for inserting videos in accordance with fill in the material.
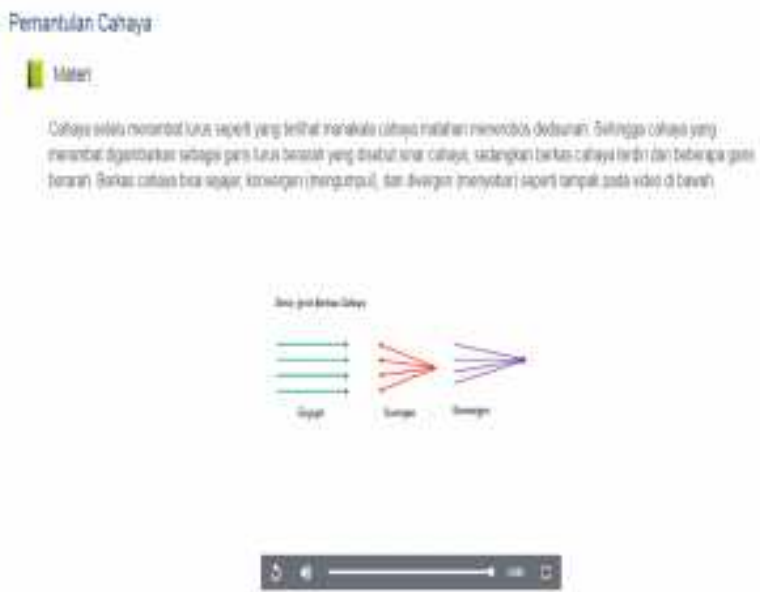

Fig. 11. Moodle Material With Book Features

The final activity of the learning process is conducting an evaluation. Moodle is one of the learning media that will greatly help a teacher's task become simpler. Moodle provides a feature to evaluate according to the teacher's wishes. Evaluation of learning outcomes can be accessed through the quiz feature. There are many types of questions available such as multiple choices, essays, matching, short answers and more. The researcher chose the type of multiple choice questions with five answer choices. Evaluation of learning outcomes is HOTS questions consisting of 15 items.

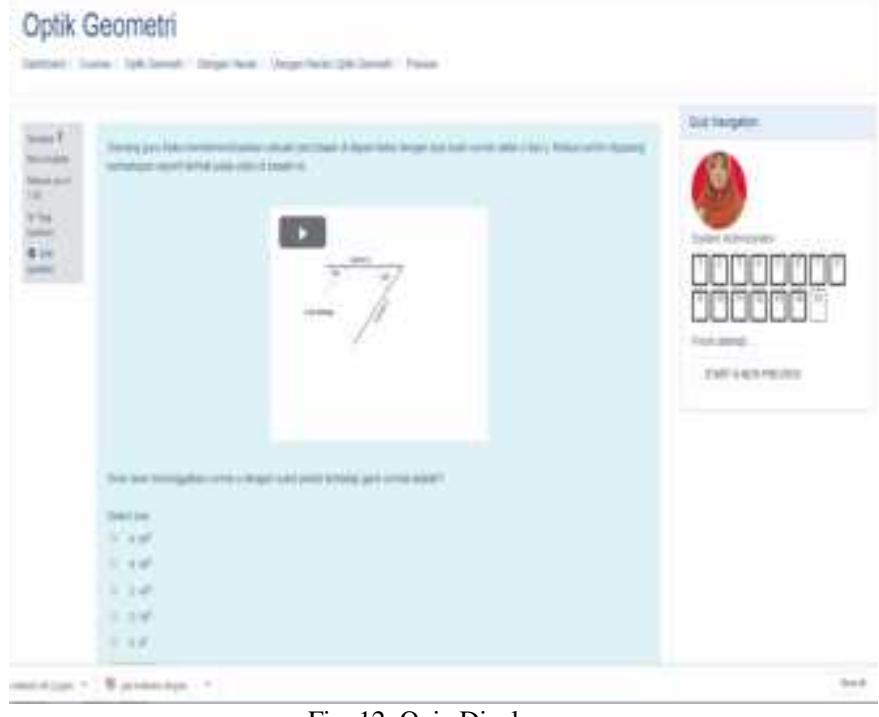

Fig. 12. Quiz Display

Assisted teacher assignments are unlimited with the quiz feature to evaluate learning outcomes. The teacher's next task is to analyze which questions are difficult for students to answer or which questions can be answered by almost all students as shown in the picture below:

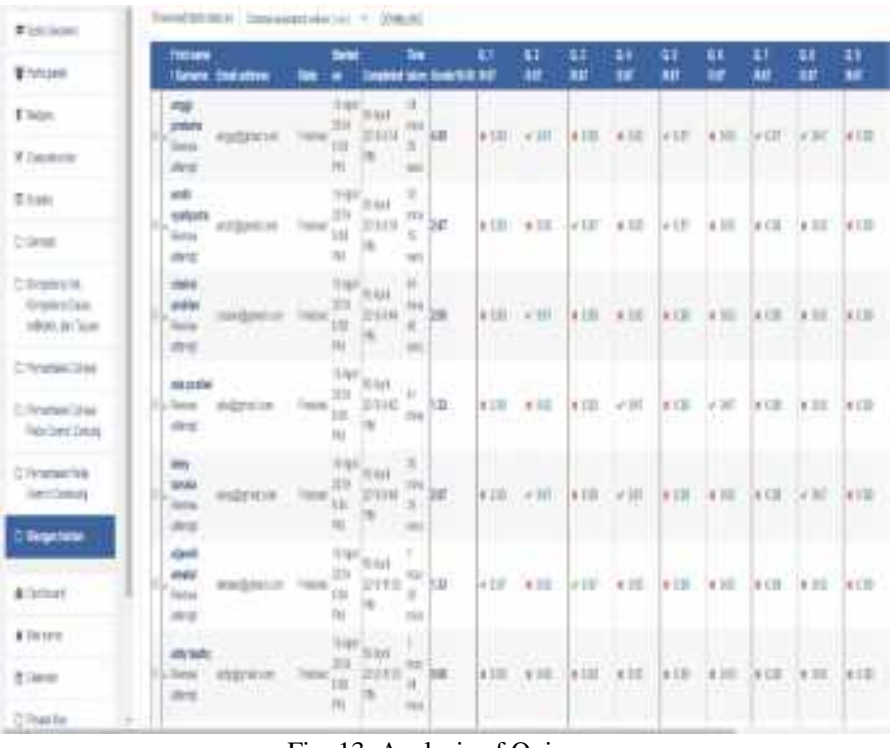

Fig. 13. Analysis of Quiz

\section{Application Testing Results}

The material expert in this study was Mr. Dr. Karya Sinulingga, M.Sc and Dr. Nurdin Siregar. M.Sc, namely lecturers from the Physics Education Study Program, Postgraduate Program, Medan State University. Validation is carried out related to four aspects, namely the aspect of content feasibility, aspects of feasibility of presentation, aspects of language feasibility, and contextual assessment. Analysis of the data from the material validation expert on moodle-based e-learning media that was developed in full can be seen in table 1. the following is a recapitulation of the judgments given by material experts.

TABLE 1. RECAPITULATION OF RESULTS OF VALIDATION BY MATERIAL EXPERTS

\begin{tabular}{|c|l|c|c|}
\hline No. & Assessment Aspect & Average & Category \\
\hline 1 & $\begin{array}{l}\text { Feasibility of Moodle as E- } \\
\text { Learning Technology }\end{array}$ & 4.35 & Worthy \\
\hline Total & 4.35 & Very Worthy \\
\hline $\begin{array}{l}\text { The overall category of material } \\
\text { feasibility is very feasible }\end{array}$ & \multicolumn{2}{|c|}{. } \\
\hline
\end{tabular}

Based on Table 1 regarding the feasibility assessment, it is known that the average score $(\mathrm{X})$ for the four aspects is 4.64 located in the range $X>4.20$ stating that the product developed by the score classification belongs to the "Very Good" category. This means that learning media are developed based on the value of the content aspects, feasibility aspects of presentation, language feasibility aspects, and contextual assessment including the Very Worthy category to be used as learning media in schools.

Media expert is Mr. Sriadhi, Ph.D. and Mr. Dr. Hermawan Syahputra, M.Sc, a lecturer from the Mathematics Education Study Program, Postgraduate Program, Medan State University. Validation is carried out related to three aspects, namely aspects of software engineering, aspects of learning design, and aspects of visual communication. Validation is done by putting a check mark $(\sqrt{ })$ on a questionnaire with five scales. The recapitulation of the results of the validation by the media experts is complete and can be seen in Appendix 22. The following is a recapitulation of the ratings provided by media experts. 
TABLE 2. RECAPITULATION OF VALIDATION RESULTS BY MEDIA EXPERTS

\begin{tabular}{|c|l|c|c|}
\hline No. & Assessment Aspect & Average & Category \\
\hline 1 & Content Feasibility & 4.53 & Very Worthy \\
\hline 2 & Feasibility of Presentation & 4.50 & Very Worthy \\
\hline 3 & Language Feasibility & 4.70 & Very Worthy \\
\hline 4 & Contextual Assessment & 4.81 & Very Worthy \\
\hline Total & 4.64 & \\
\hline $\begin{array}{l}\text { The overall category of material } \\
\text { feasibility is very feasible }\end{array}$ & \multicolumn{3}{|c|}{ Very Worthy } \\
\hline
\end{tabular}

Based on Table 2 regarding feasibility assessment, it is known that the average score $(\mathrm{X})$ for all three aspects is 4.24 located in the range $X>4.20$ stating that the product developed by the score classification belongs to the category of "Very Good". This means that learning media are developed based on the value of the software aspects of the design, learning design aspects, and aspects of visual communication including the Very Worthy category to be used as a medium of learning in school.

The technologist is Mr. Sriadhi, Ph.D. and Mr. Dr. Hermawan Syahputra, M.Sc, a lecturer from the Mathematics Education Study Program, Postgraduate Program, Medan State University. Validation was carried out related to the feasibility aspects of moodle as e-learning technology. Validation is done by putting a check mark $(\sqrt{ })$ on a questionnaire with five scales. The following is a recapitulation of the ratings provided by technology experts.

TABLE 3. RECAPITULATION OF VALIDATION RESULTS BY TECHNOLOGY EXPERTS

\begin{tabular}{|c|l|c|c|}
\hline No. & Assessment Aspect & Average & Category \\
\hline 1 & E-Learning Media Technical & 87.30 & Very Worthy \\
\hline 2 & E-Learning Media Design & 89.20 & Worthy \\
\hline \multicolumn{2}{|c|}{ Total } & 88.25 & \\
\hline $\begin{array}{l}\text { The overall category of material } \\
\text { feasibility is very feasible }\end{array}$ & \multicolumn{2}{|c|}{ Worthy } \\
\hline
\end{tabular}

Based on Table 3 regarding the feasibility assessment, it is known that the average score $(\mathrm{X})$ for the aspects of moodle feasibility as e-learning technology is 4.35 located in the range $\mathrm{X}>4.20$ stating that the product developed by the score classification belongs to the category "Very Well". This means that learning media are developed based on the value of the software aspects of the design, learning design aspects, and aspects of visual communication including the Very Worthy category to be used as a medium of learning in school.

The validator of the learning practitioner is one of the physics teachers at the Tapian DolokTaman siswa Private High School, Nyi Murniati,S.Pd. Validation is done which includes learning aspects and aspects of visual communication. Validation is done by putting a check mark $(\sqrt{ })$ on a questionnaire with five scales. The complete recapitulation of the results of validation by the physics teacher can be seen in Tabel4. The following is a recapitulation of the ratings given by media experts.

TABLE 4. RECAPITULATION OF VALIDATION RESULTS BY PHYSICS TEACHER

\begin{tabular}{|c|l|c|c|}
\hline No. & Assessment Aspect & Average & Category \\
\hline 1 & Learning & 4.25 & Very Worthy \\
\hline 2 & Visual Communication & 4.00 & Worthy \\
\hline Total & 4.12 & \\
\hline $\begin{array}{l}\text { The overall category of material } \\
\text { feasibility is very feasible }\end{array}$ & \multicolumn{3}{|l}{ Worthy } \\
\hline
\end{tabular}

Based on Table 4 regarding the feasibility assessment, it is known that the average score $(\mathrm{X})$ for the learning aspect and visual communication aspect is 4.12 located in the range of 3.4 $<\mathrm{X} 2.42$ stating that the product developed by the score classification belongs to the category "Good " This means that the learning media developed based on the value of learning aspects and aspects of visual communication are included in the Worthy category to be used as learning media in schools.

One-on-one trials were conducted on five students of class XII IPA Taman siswa Private High School Tapian Dolok. Before learning media is tested, researchers first provide an introduction to the media being developed. The researcher then instructs students to turn on their computers as devices to access learning media. Learning is done with the help of moodle-based e-learning media by accessing the address http // physicselearning.com through the local internet network facilities provided by the school. This trial was conducted for 2 hours of study. After the teaching and learning activities were completed, students were asked to fill out a questionnaire given to provide an assessment of the moodle-based e-learning media developed. The following is a recapitulation of one-on-one trial evaluations.

TABLE 5. RECAPITULATION OF RESULTS OF ONE OPPONENT ONE TEST EVALUATION

\begin{tabular}{|c|c|c|c|}
\hline No. & Assessment Aspect & Average & Category \\
\hline 1 & Software engineering & 4.20 & Worthy \\
\hline 2 & Learning Design & 4.00 & Worthy \\
\hline 3 & Visual Communication & 4.52 & Very Worthy \\
\hline \multicolumn{2}{|c|}{ Total } & 4.24 & \\
\hline \multicolumn{2}{|c|}{$\begin{array}{l}\text { The overall category of material } \\
\text { feasibility is very feasible }\end{array}$} & \multicolumn{2}{|c|}{ Very Worthy } \\
\hline
\end{tabular}

Based on Table 5 regarding the formula for actual score conversion to a scale of five, it is known that the average score (X) for both aspects is $88.25 \%$, which lies in the range which states that the product developed is included in the "Very Good" category. The results of the one-on-one trial evaluation show that learning media developed based on the value of elearning media technical aspects and e-learning media design aspects include the Very Worthy category to use.

One-on-one trials were conducted on ten students of class XII IPA Taman siswa Private High School Tapian Dolok. Before learning media is tested, researchers first provide an introduction to the media being developed. The researcher then instructs students to turn on their computers as devices to access learning media. Learning is done with the help of moodle-based e-learning media by accessing the address http // physicselearning.com through the local internet network facilities provided by the school. This trial was conducted for 2 hours of study. After the teaching and learning activities were completed, students were asked to fill out a questionnaire given to provide an assessment of the moodle-based e-learning media developed. Next is a recapitulation of the assessment of small group trials.

TABLE 6. RECAPITULATION OF RESULTS OF SMALL CLASS

\begin{tabular}{|c|l|c|c|}
\hline No. & Assessment Aspect & Average & Category \\
\hline 1 & E-Learning Media Technical & 88.20 & Very Worthy \\
\hline 2 & E-Learning Media Design & 86.20 & Worthy \\
\hline Total & 88.72 & \\
\hline $\begin{array}{l}\text { The overall category of material } \\
\text { feasibility is very feasible }\end{array}$ & \multicolumn{2}{|c|}{ Worthy } \\
\hline
\end{tabular}

Based on Table 6 regarding the formula for actual score conversion to a scale of five, it is known that the average score (X) for both aspects is $88.72 \%$, which lies in the range which 
states that the product developed is included in the category of "Very Good". The results of the assessment of the small group test show that the learning media developed based on the value of the technical aspects of e-learning media and the design aspects of e-learning media include the Very Worthy category to use.

Field trials were conducted on twenty science education students from Medan State University. Before learning media is tested, researchers first provide an introduction to the media being developed. The researcher then instructs students to turn on their computers as devices to access learning media. Learning is done with the help of moodle-based e-learning media by accessing the address http // physicselearning.com through an internet local network facility provided by the Unimed postgraduate computer laboratory. This trial is carried out for 1 hour. After the teaching and learning activities were completed, students were asked to fill out a questionnaire given to provide an assessment of the moodle e-learning media developed. The following is a recapitulation of the field trial assessment.

Table 7. Recapitulation of Results of Real Class

\begin{tabular}{|c|l|c|c|}
\hline No. & Assessment Aspect & Average & Category \\
\hline 1 & E-Learning Media Technical & 85.30 & Very Worthy \\
\hline 2 & E-Learning Media Design & 82.70 & Vey Worthy \\
\hline Total & 84.00 & \\
\hline $\begin{array}{l}\text { The overall category of material } \\
\text { feasibility is very feasible }\end{array}$ & \multicolumn{2}{|c|}{ Very Worthy } \\
\hline
\end{tabular}

Based on Table 7 regarding the formula for actual score conversion to a five-scale value, it is known that the average score $(\mathrm{X})$ for both aspects is $84.00 \%$ which lies in the range which states that the product developed is included in the "Very Good" category. The results of the field trial assessment indicate that the learning media developed based on the value of the technical aspects of e-learning media and the design aspects of e-learning media include the Very Worthy category to use.

\section{DISCUSSION}

This research is the development of learning media in the form of moodle e-learning media on geometric optical material for participants student in class XI high school. Development of learning media through four stages of development, namely define, design, develop, and disseminate. Descriptions of activities carried out at each stage of development along with the results obtained have been described in the results section of the research discussed earlier.

Development products in the form of moodle e-learning learning media are then assessed for the level of quality, validity, practicality, and effectiveness to obtain learning media that are valid, practical, and effective so that they are truly suitable for use as learning resources.

Expert feasibility assessments of learning media that can be accessed through moodle e-learning on geometric optical material as a whole are critically feasible. Herayanti et al [5] stated that the development of moodle media was declared 'feasible' to support the learning process in lectures. Moodle media that are developed contain material, examples of questions, animation that is in accordance with the material, activities, resources, forums, quizzes and assignments. Products developed have the advantage of improving the quality of learning that is more interesting and controlled. The same thing was revealed by Hartawan and Pudjawan [6] who obtained a product in the form of a moodle e-learning portal on physics subjects in the $\mathrm{X}$ grade in the even semester at Dwijendra High School Denpasar. The moodle-based elearning portal is categorized very well based on expert tests. Setiyorini et al [7] also stated that the development of learning media in the form of moodle on temperature and heat material is feasible to be used as a medium of physics learning in schools.

This moodle learning media contains material also equipped with examples of questions and display animations that correspond to each material. The use of moodle learning media in this research is done by combining face-to-face learning and online learning. Online learning is a system that can facilitate students to learn more broadly and more widely [8]. Yeung [9] emphasizes that web-based distance learning is important for all types of learning. Feedback that occurs to students is much better and more effective. Puspitasari [10] added that e-learning media with moodle on business and energy concepts can help the learning process in schools become more independent and can monitor the development of students outside of school because material, training and quizzes can be accessed anytime and anywhere.

\section{V.CONCLUSION}

Based on the results of research and discussion, it can be concluded that the moodle e-learning media that is feasible is used as a medium for learning the physics of geometric optical matter.

\section{REFERENCES}

[1] Lee, J., Lapira, E., Bagheri, B., \& Kao, H., (2013). Recent Advances and Trends in Predictive Manufacturing Systems in Big Data Environment. Manuf. Lett. 1 (1), 38-41.

[2] Liffler, M., \&Tschiesner, A. (2013). The Internet of Things and the Future of Manufacturing. McKinsey \& Company.

[3] Prakoso, K. (2005). Membangun E-Learning dengan Moodle. Yogyakarta: ANDI.

[4] Hartanto, A.A., \&Purbo, O.W. (2005). Teknologi E-Learning Berbasis php dan mysql. Jakarta: Elek Media Komputindo.

[5] Herayanti, L., Fuaddunnazmi, M., \&Habibi. (2016). Pengembangan Media Pembelajaran Berbasis Moodle untuk Meningkatkan Keterampilan Berpikir Kreatif Calon Guru Fisika. Prosiding Seminar Nasional Fisika 2016. 86-91

[6] Hartawan, I.K.A., Tastra, I..K., \&Pudjawan, K. (2014).Pengembangan Portal E-Learning Berbasis Moodle pada Mata PelajaranFisikaKelas X di SMA Dwijendra Denpasar. Jurnal Edutech Universitas Pendidikan Ganesha, 1 (2), 1-12.

[7] Setiyorini, Patonah, S., \&Murniati, N.A.N. (2016). Pengembangan Media Pembelajaran Moodle.Jurnal Penelitian Pengembangan Fisika. 7 (2), 156-160

[8] Marhaenanto, B., dan Fatahillah, A. (2016). E-Learning Universitas Jember. Jember: LP3 Jember.

[9] Yeung, D. (2003). Toward an Effective Quality Assurance of Web-Based Learning:The Perspective of Distance Learning Students. Turkish Online Journal of Distance Education-TOJDE. 4 (1), 1-12.

[10] Puspitasari, W.D. (2018). Pengembangan Media E-Learning dengan Moodle sebagai Suplemen Pembelajaran Fisika pada Konsep Usaha dan Energi. Skripsi. 